\title{
ẢNH HƯỞNG CỦA HORMONE GROWTH VÀ INSULIN GROWTH FACTOR 1 ĐỐI VỚI SỤ๋ TĂNG TRƯỞNG XƯƠNG THEO TRỤC DQ̣C
}

\section{Effects of Hormone Growth and Insulin Growth Factor 1 on Longitudinal Bone Growth}

Ngày nhận bài: 03/01/2017; ngày phản biện: 22/2/2017; ngày duyệt đăng: 22/3/2017

Trần Long Giang*

\section{TÓM TẮT}

Hormone Growth $(\mathrm{GH})$ và Insulin Growth Factor 1 (IGF-I) có vai trò quan trọng trong sự phát triển chiều cao cơ thể thông qua các tác động lên xương. Nhiều công trình nghiên cứu trên người và động vật cho thấy GH kích thích trực tiếp sự phát triển xương theo trục dọc bằng cách kích thích các nguyên bào sụn trong đĩa tăng trưởng theo cơ chế nhân dòng vô tính và IGF -I kích thích các tế bào ở các giai đoạn sau bằng cách làm giảm thời gian chu kỳ tế bào. Ngoài ra, GH và $\mathrm{IGF}-\mathrm{I}$ cũng phát huy tác động bổ trợ hoặc tương tác với nhau khi chúng được đưa vào cơ thể cùng nhau.

Từ khóa: Hormone Growth, Insulin Growth Factor 1, tăng trương xuơng, nguyên bào xương

\section{ABSTRACT}

Growth hormone (GH) and Insulin Growth Factor 1 (IGF-I) plays an important role in the development of body height through the effects on bone. Many studies in humans and animals shows that GH stimulates longitudinal bone growth directly by stimulating prechondrocytes in the growth plate followed by a clonal expansion and IGF-I stimulates cells in the later stages by reducing the cell cycle time. In addition, GH and IGF-I also promote additional effects or interact with each other when they are brought into the body together.

Keywords: Hormone Growth; Insulin Growth Factor 1; bone growth; osteoblasts.

\section{Mở đầu}

Hormone Growth $(\mathrm{GH})$ được bài tiết từ tuyến yên, xuất hiện ở phôi thai người từ khoảng tuần thứ 9 . GH có nhiều tác dụng chuyển hóa như kích thích đồng hóa protid, làm tăng sự xâm nhập các acide amin vào trong tế bào và tổng hợp protein, đặc biệt ở cơ, gan và xương [1]. Tác dụng của $\mathrm{GH}$ trên cơ và thận gần đây đã được đề cập bởi Florini và cộng sụ [6] và Feld và Hirschberg [5]. Với bài báo này, chúng tôi chỉ tập trung giới thiệu về những hiểu biết đến thời điểm hiện tại về các tác dụng của GH trên xương theo trục dọc.

Ở trẻ em, giai đoạn trước 6 tuổi và giai đoạn dậy thì có sự gia tăng mạnh nhất về khối lượng xương thông qua hình thành xương nội sụn. Khối lượng xương tăng dần theo tuổi và đạt mức lớn nhất ở giai đoạn 20 đến 30 tuổi. Sau đó, khối lượng xương giảm dần, đặc biệt giảm nhanh ở phụ nữ sau mãn kinh.

Sự tái tạo xương được quy định bởi sự cân bằng giữa tiêu xương và hình thành xương. Trong quá trình này $\mathrm{GH}$ đóng một vai trò rất quan trọng. Sự tăng của khối lượng xương do sự hình thành xương mới dưới tác dụng của GH lần đầu tiên được phát hiện ở những con chó lai trưởng thành [theo 6], sau khi cho điều trị với GH trong 3 tháng đã tăng $2 \%$ trong khối lượng vỏ xương.

Do một số cơ thể bị hạn chế trong việc sản xuất $\mathrm{GH}$, một số nghiên cứu trên động vật và nghiên cứu lâm sàng ở người đã được thực

\footnotetext{
*Trung tâm dạy nghề và Giáo dục thường xuyên - Văn Yên - Yên Bái
} 
hiện cho đến giữa những năm 1980, khi sự tái tổ hợp $\mathrm{GH}$ ở người được ứng dụng trong nghiên cứu. Ban đầu, việc sử dụng sản phẩm GH tái tổ hợp bị hạn chế trong việc điều trị cho trẻ em tăng trưởng chậm do thiếu hụt $\mathrm{GH}$. Thiếu GH cũng gây ảnh hưởng nghiêm trọng ở người lớn. Việc điều trị thiếu hụt $\mathrm{GH}$ ở người trưởng thành cũng đã được chấp nhận ở một số quốc gia. Nhiều nghiên cứu gần đây trên cả người và động vật đã chứng minh $\mathrm{GH}$ gây tác động mạnh đến xương.

IGF-1 (Insulin Growth Factor 1) là một hoạt chất trung gian hòa giải chính của những tác động của hormone tăng trưởng (GH). Hormone tăng trưởng được sản xuất tại tuyến yên, được đưa vào trong máu và sau đó kích thích gan sản xuất IGF-I. Sau đó, IGF-1 kích thích sự tăng trưởng của cơ thể, đồng thời thúc đẩy tác động tăng trưởng trên hầu hết các tế bào trong, đặc biệt là cơ xương cơ, khớp, sụn, gan, thận, phổi, dây thần kinh, da và tế bào tạo máu. Ngoài ra, IGF-I cũng điều tiết tăng trưởng và phát triển tế bào, đặc biệt là các tế bào thần kinh, cũng như các tế bào DNA tổng hợp [1].

Trong bài báo này chúng tôi bàn về vai trò của $\mathrm{GH}$ trong quá trình phát triển xương cho đến khi khối lượng xương đạt được giá trị tối đa. Tổng hợp các nghiên cứu thấy rằng $\mathrm{GH}$ kích thích trực tiếp sự phát triển xương theo trục dọc bằng cách kích thích các tế bào tiền sụn trong đĩa tăng trưởng theo cơ chế nhân dòng vô tính gây ra bởi cả $\mathrm{GH}$ được sản xuất tại chỗ nhờ Insulin Growth Factor 1(IGF-I) và sự tăng GH do tăng nồng độ IGF-I trong tuần hoàn máu.

\section{Nội dung}

\subsection{Hormone Growth và sự quy định} của phát triển xương sau khi sinh theo trục dọc

Trong quá trình phát triển xương theo trục dọc, các nguyên bào sụn trong các lớp tế bào mầm khác nhau trải qua các quá trình phân bào tạo ra đĩa sụn ở đầu xương. Sau đó các lớp tế bào sụn trưởng thành rồi thoái hóa và được đẩy vào trong để hóa xương [10].

Có một số hormone quan trọng cho sự phát triển xương bình thường theo trục dọc sau khi sinh, trong số đó GH là loại hormone quan trọng nhất. Hơn nữa, $\mathrm{GH}$ đã được chứng minh là hormone kích thích sự phát triển của sụn và các mô khác bằng cách tăng số lượng tế bào chứ không phải tăng kích thước tế bào. Một vấn đề được thảo luận rộng rãi trong nhiều thập kỷ qua là $\mathrm{GH}$ tác động trực tiếp lên các mô hay qua một yếu tố trung gian có nguồn gốc từ gan ảnh hưởng đến sự tăng trưởng, ban đầu được gọi là yếu tố Sulfat, nhưng sau đó đổi tên thành Somatomedin và sau đó được phát hiện là trùng với IGF-I. Theo giả thuyết ban đầu về Somatomedin, GH kích thích tăng trưởng xương bằng cách kích thích gan sản xuất Somatomedin. Sau đó, lần lượt kích thích sự phát triển xương theo chiều dọc bằng hệ thống nội tiết [4].

Trong nửa đầu những năm 1980, giả thuyết Somatomedin đã được thử thách bởi một nghiên cứu cho rằng tiêm trực tiếp $\mathrm{GH}$ vào đĩa tăng trưởng xương chày của chuột sẽ kích thích sự phát triển xương theo trục dọc ở vị trí tiêm. Quan sát này sau đó đã được khẳng định và mở rộng, bây giờ nhiều tài liệu cho rằng $\mathrm{GH}$ kích thích tăng trưởng trực tiếp lên nhiều mô khác nhau [11].

Bằng cách nghiên cứu các tác động của GH và IGF-I trên dòng tế bào $3 T 3$ preadipocytes, Zezulak và cộng sụ [11] đã quan sát thấy $\mathrm{GH}$ và IGF-I hoạt động trên các tế bào ở các giai đoạn khác nhau của sự trưởng thành. $\mathrm{GH}$ được xác định là kích thích tiền tế bào mỡ (trong nhóm các tế bào nền gồm tế bào mỡ, tế bào sụn và tế bào xương), trong khi IGF-I kích thích các tế bào ở giai đoạn sau của 
sự phát triển. Giả thuyết của Zezulak và cộng sụ cho rằng $\mathrm{GH}$ tác động lên tế bào tiền thân (đời thứ nhất của tế bào gốc) và IGF-I kích thích mở rộng dòng vô tính tiếp theo (kích thích phân bào), được gọi là "lý thuyết ảnh huoơng kép". Phát hiện $\mathrm{GH}$ kích thích sự phát triển xương trực tiếp theo trục dọc và làm tăng sản xuất tại chỗ của IGF-I bằng cách kích thích phiên mã của gen IGF -I dẫn đến đề xuất cho rằng "lý thuyết ảnh huoòng kép" của $\mathrm{GH}$ cũng có tác dụng quy định của sự phát triển xương theo trục dọc [10]. Tiếp theo, với nghiên cứu nuôi tế bào sụn đầu xương trong ống nghiệm đã chứng minh rằng $\mathrm{GH}$ và $\mathrm{IGF-I}$ kích thích các tế bào ở các giai đoạn khác nhau của sự trưởng thành. Như vậy, GH kích thích sự hình thành nhóm tế bào tiền sụn, trong khi IGF -I kích thích các tế bào ở giai đoạn sau của sự trưởng thành, đã ủng hộ giả thuyết cho rằng tế bào trưởng thành thực sự là một yếu tố quan trọng quyết định sự đáp ứng của sụn đầu xương với $\mathrm{GH}$ và IGF-I [9]. Giả thuyết $\mathrm{GH}$ ưu tiên tác động trên nguyên bào sụn trong cơ thể được củng cố bởi một nghiên cứu từ phòng thí nghiệm của Ohlson [9]. Bằng cách đánh dấu các tế bào tiền sụn theo chu kỳ bởi nguyên tố phóng xạ Thymidine và nghiên cứu mô hình đánh dấu trong phần dọc của đĩa tăng trưởng xương chày bằng chụp $\mathrm{X}$ quang tự động, các quan sát quá trình thực hiện tiêm GH tại chỗ đã làm tăng số lượng tế bào thuộc nhóm được dán nhãn trong lớp tế bào tiền sụn của tấm tăng trưởng. Ngược lại, không phát hiện thấy IGF-I kích thích các tế bào trong cùng một lớp nguyên bào sụn khi có kết hợp của thymidine phóng xạ [9]. Sử dụng kỹ thuật histomorphometric, người ta thấy $\mathrm{GH}$ cũng như IGF-I có khả năng kích thích tế bào tiền sụn, vì cả GH và IGF-I đều có khả năng làm giảm thời gian chu kỳ tế bào của tế bào tiền sụn. Tuy nhiên, trong các nghiên cứu tương tự, các tế bào tiền sụn của đĩa tăng trưởng ở động vật được điều trị bởi $\mathrm{GH}$ có thời gian chu kỳ tế bào ngắn hơn $50 \%$ so với động vật được điều trị bởi IGF-I [9]. Những dữ liệu này cho thấy ít nhất một số tác dụng thúc đẩy tăng trưởng của GH được thông qua kích thích trực tiếp lên các tế bào tiền sụn.

\subsection{Vai trò sinh lý của IGF -I cho sự} phát triển xương

Nghiên cứu thực hiện trong 20 năm liên quan đến hệ thống kiểm soát ở người và động vật thiếu GH cho thấy, cả IGF-I và GH đều có khả năng kích thích sự phát triển xương theo trục dọc trong cơ thể [10]. Loại bỏ IGF-I và các thụ thể IGF-I bởi sự tái tổ hợp gen tương đồng đã chứng minh con đường tín hiệu IGF-I là rất quan trọng cho sự phát triển các mô và sự tăng trưởng xương. Do đó, những con chuột thiếu hụt IGF-I cho thấy mức độ nghiêm trọng của sự chậm phát triển tầm vóc mà đáng ra phải rõ ràng vào ngày thứ 12 trong trong giai đoạn phôi thai, dẫn đến sự chậm tăng trưởng một cách nghiêm trọng sau khi sinh [8]. Những con chuột bị loại bỏ thụ thể IGF-I sẽ bị ảnh hưởng một cách nghiêm trọng và bị chết sớm vì suy hô hấp sau khi sinh do sự phát triển kém của cơ hô hấp [8]. Hơn nữa, một bệnh nhân bị mất một gen IGF-I cho thấy cho sự chậm phát triển trong tử cung và em bé bị suy dinh dưỡng sau khi sinh [10]. Những nghiên cứu thực nghiệm và quan sát lâm sàng chứng minh rằng sự bình thường của IGF-I, cũng như thụ thể của nó, đóng một vai trò quan trọng cho sự phát triển bình thường của cơ thể và phát triển mô. Tuy nhiên, những kết luận này không thể trả lời được câu hỏi liệu sản xuất tại chỗ (autocrine/paracrine thay thế) IGF-I quan trọng hơn cho sự tăng trưởng và phát triển các mô so với sự lưu thông trong hệ nội tiết của IGF -I?

Một số nghiên cứu đã chỉ ra rằng hệ thống tái tổ hợp IGF-I kích thích sự phát triển 
xương theo trục dọc cũng như tăng trọng lượng cơ thể ở chuột hypophysectomized, bổ sung cho lý thuyết IGF-I có tác dụng nội tiết làm tăng trưởng tầm vóc. Điều thú vị là IGF -I đặc biệt thúc đẩy sự phát triển của các mô không xương. Vì vậy, tác động của IGF-I trên thận, lá lách, tuyến ức làm tăng trưởng mạnh hơn so với ở các mô khác. Sự khác biệt về loại mô để đáp ứng IGF-I cũng được tìm thấy ở những con chuột biến đổi gen biểu hiện tốt với IGF -I, cho thấy IGF-I có chức năng đặc biệt quan trọng trong các mô không xương [3]. Những dữ liệu này chứng minh rằng hệ thống nội tiết của IGF-I có khả năng thúc đẩy tăng trưởng ở động vật.

\section{3. Đánh giá lý thuyết Somatomedin so với "lý thuyết ảnh hưởng kép"}

Thực tế thì cả GH và IGF-I đều kích thích tăng trưởng các mô, giải mã về tầm quan trọng tương đối của các peptide cho tác động về mặt mô hình không gian và thời gian là khá phức tạp. Có vẻ hợp lý nếu đánh giá dữ liệu thực nghiệm và dữ liệu lâm sàng để tìm hiểu làm thế nào dữ liệu lâm sàng phù hợp với hai lý thuyết khác nhau, lý thuyết Somatomedin và lý thuyết ảnh huởng kép. Hiệu quả nội tiết của GH và IGF-I đối với chuột hypophysectomized cho thấy $\mathrm{GH}$ và IGF-I có tính độc lập và khác biệt giữa các chức năng. Khi hai hormone này được tiêm vào cơ thể cùng nhau, chúng phát huy tác động bổ trợ hoặc tương tác với nhau. Ngoài ra, bổ sung GH vào động vật được điều trị với liều tối đa của IGF-I sẽ kích thích tăng trưởng mạnh hơn [11]. Mặt khác, sự khác biệt giữa $\mathrm{GH}$ và IGF-I là khá rõ ràng ở động vật biến đổi gen biểu hiện tốt với GH hoặc IGF-I. Ở động vật biến đổi gen GH, làm tăng lên khoảng hai lần kích thước của lứa chuột đẻ bình thường [3]. Ngược lại, những con chuột được tạo ra từ phép lai giữa những con chuột biểu hiện tốt IGF-I và những con chuột thiếu GH thể hiện sự gia tăng phát triển xương theo trục dọc và trọng lượng cơ thể khi so sánh với các các con chuột đối chứng thiếu GH. Tuy nhiên, những con chuột biến đổi gen IGF-I có kích thước không lớn hơn so với anh chị em của chúng không biến đổi gen [3], cho thấy nếu nồng độ $\mathrm{GH}$ quá cao, nhưng không có IGF-I là nguyên nhân của tăng trưởng trên bình thường. Tiêm GH, nhưng không bổ sung IGF-I sẽ kích thích sản xuất tại chỗ IGF-I bằng cách kích thích phiên mã của gen IGF-I [2], thử nghiệm này bổ sung thêm cho quan điểm cho rằng có tương tác giữa $\mathrm{GH}$ và IGF-I. Sử dụng các kháng thể đối với IGF-I và bãi bỏ hiệu ứng kích thích tại chỗ của $\mathrm{GH}$ [3], cho rằng IGF-I tại chỗ có vai trò quan trọng trong sự biểu hiện của tác động của GH tại vị trí mô [10].

Điều trị hội chứng thiếu GH của bệnh nhân với tái tổ hợp IGF-I cho thấy IGF-I khá hiệu quả trong việc kích thích tăng trưởng tầm vóc từ 1 đến 2 năm [2], điều này cũng bổ sung cho lý thuyết Somatomedin. Tuy nhiên, dữ liệu lâm sàng cho thấy tác động của IGF-I sau đó trở nên ít hiệu quả, có lẽ do tốc độ giảm kích thích của các nguyên bào sụn. Tuy nhiên, từ những nghiên cứu lâm sàng rất khó để đưa ra kết luận chung, mặc dù IGF-I kích thích tăng trưởng mô theo cơ chế nội tiết hoặc cơ chế autocrine/paracrine trong những trường hợp sinh lý trong cơ thể còn nguyên vẹn.

\section{Kết luận}

Theo lý thuyết Somatomedin, cả GH và IGF-I đều có vai trò quan trọng đối với sự phát triển xương theo trục dọc. GH kích thích tăng trưởng xương bằng cách kích thích gan sản xuất Somatomedin, có tác dụng kích thích mô xương và sụn phát triển. Với nồng độ rất thấp IGF-I đã có tác dụng tưong tự như một $\mathrm{GH}$ ở nồng độ rất cao chứng tỏ hầu hết chức năng trao đổi chất của GH không thông qua ảnh 
hưởng trực tiếp của nó đến các mô mà thông qua tác dụng của các Somatomedin.

Theo lý thuyết ảnh hưởng kép, $\mathrm{GH}$ và IGF -I kích thích các tế bào xương ở các giai đoạn khác nhau của sự trưởng thành. GH kích thích làm tăng số lượng các nguyên bào sụn và IGF-I kích thích sự phân bào bằng cách làm giảm thời gian chu kỳ tế bào.
Thực tế thì cả GH và IGF-I đều kích thích tăng trưởng xương theo trục dọc, giải mã về tầm quan trọng tương đối của các peptide cho tác động về mặt mô hình không gian và thời gian là khá phức tạp và cần tiến hành nhiều nghiên cứu lâm sàng để làm sáng tỏ vấn đề này.

\section{TÀI LIỆU THAM KHẢO}

1. Trần Long Giang, Nguyễn Cửu Nguyệt Huế (2014), Ảnh hưởng của Hormone Growth và Insulin Growth Factor 1 đối với sự tăng trưởng xương trong nghiên cứu In vitro, Tạp chí khoa học Trường Đại học Sư phạm Tp. Hồ Chí Minh (64), tr.148-154.

2. Backeljauw PF, Underwood LE (1996). Prolonged treatment with recombinant insulin-like growth factor-I in children with growth hormone insensitivity syndrome-a clinical research center study. GHIS Collaborative Group. J Clin Endocrinol Metab 81: 3312-3317.

3. Behringer RR, Lewin TM, Quaife CJ, Palmiter RD, Brinster RL, D’Ercole AJ (1990). Expression of insulin-like growth factor I stimulates normal somatic growth in growth hormone-deficient transgenic mice. Endocrinology 127: 1033-1040.

4. Daughaday WH, Rotwein P (2009). Insulin-like growth factors I and II. Peptide, messenger ribonucleic acid and gene structures, serum, and tissue concentrations. Endocr Rev 10: 68-91.

5. Feld S, Hirschberg R (1996). Growth hormone, the insulin-like growth factor system, and the kidney. Endocr Rev 17: 423-480.

6. Florini JR, Ewton DZ, Coolican SA (2006). Growth hormone and the insulin-like growth factor system in myogenesis. Endocr Rev 17: 481-517.

7. Holloway L, Kohlmeier L, Kent K, Marcus R (1997). Skeletal effects of cyclic recombinant human growth hormone and salmon calcitonin in osteopenic postmenopausal women. J Clin Endocrinol Metab 82: 1111-1117.

8. Liu JP, Baker J, Perkins AS, Robertson EJ, Efstratiadis A (1993). Mice carrying null mutations of the genes encoding insulin-like growth factor I (Igf-1) and type 1 IGF receptor (Igf1r). Cell 75: 59-72.

9. Ohlsson C, Isaksson O, Lindahl A (2004). Clonal analysis of rat tibia growth plate chondrocytes in suspension culture-differential effects of growth hormone and insulin-like growth factor I. Growth Regul 4: 1-7.

10. Woods K, Camacho-Hubner C, Savage M, Clark A (1996). Intrauterine growth retardation and postnatal growth failure associated with deletion of the insulin-like growth factor gene. $N$ Engl $J$ Med 335: 1363-1367.

11. Zezulak KM, Green H (1986). The generation of insulin-like growth factor-1-sensitive cells by growth hormone action. Science 233: 551-553. 